\title{
Herbal prescription, Danggui-Sayuk-Ga-Osuyu-Senggang-Tang, inhibits TNF- $\alpha$-induced epithelial-mesenchymal transition in HCT116 colorectal cancer cells
}

\author{
KANGWOOK LEE ${ }^{1}$, SUNG-GOOK $\mathrm{CHO}^{2}$, YOUN KYUNG $\mathrm{CHOI}^{3}$, YU-JEONG CHOI ${ }^{1}$, \\ GYU-RI LEE ${ }^{1}$, CHAN-YONG JEON ${ }^{4}$ and SEONG-GYU KO ${ }^{5}$
}

\author{
${ }^{1}$ Department of Science in Korean Medicine, Graduate School, Kyung Hee University, Seoul 02453; \\ ${ }^{2}$ Department of Biotechnology, Korea National University of Transportation, Chungbuk 27469; ${ }^{3}$ Jeju International Marine \\ Science Center for Research and Education, Korea Institute of Ocean Science and Technology (KIOST), Jeju 63349; \\ ${ }^{4}$ Department of Korean Internal Medicine, College of Korean Medicine, Gachon University, Seongnam 13120; \\ ${ }^{5}$ Department of Preventive Medicine, College of Korean Medicine, Kyung Hee University, Seoul 02453, Republic of Korea
}

Received March 4, 2017; Accepted September 28, 2017

DOI: $10.3892 / \mathrm{ijmm} .2017 .3241$

\begin{abstract}
Tumor necrosis factor- $\alpha$-mediated (TNF- $\alpha$ ) epithelial-mesenchymal transition (EMT) is associated with distant metastasis in patients with colorectal cancer with poor prognosis. Although traditional herbal medicines have long been used to treat colorectal cancer, the incidence and mortality in patients with colorectal cancer has continued to increase. Danggui-Sayuk-Ga-Osuyu-Saenggang-Tang (DSGOST) has long been used for treatment of chills, while few studies have reported its anticancer effect. This study aimed to demonstrate the inhibitory effect of DSGOST on TNF- $\alpha$-mediated invasion and migration of colorectal cancer HCT116 cell lines. MTT was used to measure cell viability. Wound healing and Transwell invasion assay were used to detect migration and invasion of cells, respectively. The intracellular localization of proteins of interest was assessed by immunocytochemistry. Western blotting was performed to determine the expression level of various proteins. A non-toxic dose of DSGOST $(50 \mu \mathrm{g} / \mathrm{ml})$ on HCT116 cells was determined by MTT assay. Furthermore, DSGOST prevented the TNF- $\alpha$-induced invasive phenotype in HCT116 cells. DSGOST inhibition of the invasive phenotype was also associated with increased expression of EMT markers. Furthermore, DSGOST treatment blocked TNF- $\alpha$-induced migration and invasion of HCT116 cells. In addition, DSGOST treatment inhibited TNF- $\alpha$-mediated nuclear translocation of Snail. DSGOST treatment also downregulated TNF- $\alpha$-induced
\end{abstract}

Correspondence to: Professor Seong-Gyu Ko, Department of Preventive Medicine, College of Korean Medicine, Kyung Hee University, Kyungheedae-ro 24, Dongdaemun-gu, Seoul 02453, Republic of Korea

E-mail: epiko@khu.ac.kr

Key words: colorectal cancer, tumor necrosis factor- $\alpha$, invasion, migration, epithelial-mesenchymal transition, Snail, DangguiSayuk-Ga-Osuyu-Saenggang-Tang phosphorylation of AKT and glycogen synthase kinase- $3 \beta$. Therefore, the findings of the current study suggest that DSGOST exhibits anti-migration and anti-invasion effects in TNF- $\alpha$-treated HCT116 human colorectal cells.

\section{Introduction}

Colorectal cancer is one of leading causes of cancer-associated mortality worldwide $(1,2)$. Despite advances in detection and therapy in previous years, the incidence and mortality in patients with colorectal cancer is still increasing throughout the world (3-6). The major cause of mortality patients with colorectal cancer is distant metastasis to other organs, such as the liver (7), lung (8), brain (9) and bone (10). Chronic inflammation has emerged as a key contributor for development and metastasis of cancer, including colorectal carcinoma $(11,12)$. Inflammatory cytokines, such as tumor necrosis factor- $\alpha$ (TNF- $\alpha)$, interleukins (ILs), including IL-8, IL-6 and IL-1 $\beta$, promote cancer progression (13). Among them, TNF- $\alpha$ contributes to proliferation and metastasis of colorectal cancer cells and its increased expression is often correlated with poor prognosis of patients (14). Although TNF- $\alpha$ expression has been considered to be a double-edged sword in cancer, it has been suggested that targeting TNF- $\alpha$ may be a successful strategy for cancer treatment $(14,15)$. Activation of the TNF- $\alpha$ pathway promotes nuclear translocation of Snail transcription factor proteins (16). This translocation promotes epithelial-mesenchymal transition (EMT), a process that is considered to be a prerequisite for metastasis in various types of cancer, including colorectal cancer (17-21). Furthermore, Snail overexpression in patients with colorectal cancer has also been correlated with aggressiveness and poor prognosis $(22,23)$. Therefore, inhibition of TNF- $\alpha$-induced EMT is likely to be effective for treatment of colorectal cancer.

Protein kinase B (AKT), one of the mitogen-activated protein kinases (MAPKs), regulates proliferation, differentiation, development, transformation and apoptosis (24). Disturbance of phosphoinositide 3-kinase/AKT signaling is associated with cancer progression and poor prognosis (25). 
Deregulated AKT phosphorylates glycogen synthase

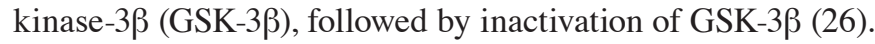
Inactivated GSK- $3 \beta$ fails to tag Snail protein for ubiquitination and subsequent degradation (26). As Snail stabilization is tightly regulated by AKT/GSK-3 $\beta$ pathways, targeting this pathway is a promising strategy for cancer treatment. It has been reported that various anticancer agents inhibit tumor growth via suppressing AKT/GSK-3ß/Snail signaling (27-31).

Traditional herbal medicines have previously been researched for colorectal cancer treatment (32-37). Danggui-Sayuk-Ga-Osuyu-Saenggang-Tang (DSGOST; Danggui-Sini-Jia-Wuzhuyu-Shengjian-Tang in Chinese, Tokishigyakukagoshuyushokyoto in Japanese) has long been used to cure patients suffered from Raynaud's syndrome $(38,39)$, dysmenorrhea (40), atopic dermatitis (41), but not cancer. Choi et al (42) initially suggested a new use for DSGOST in the treatment of cancer as DSGOST was shown to inhibit pancreatic tumor growth and metastasis by suppressing vascular endothelial growth factor (VEGF)/VEGF receptor 2-dependent tumor angiogenesis. Furthermore, Nagata et al (43) demonstrated the inhibitory effect of DSGOST on growth of gastric cancer cells. Taken together, we hypothesize that DSGOST may be beneficial for cancer treatment.

In present study, the anticancer effect of DSOGST on TNF- $\alpha$-mediated metastatic phenotypes was examined in HCT116 colorectal cancer cells. A non-cytotoxic dose of DSGOST inhibited TNF- $\alpha$-induced migration and invasion of HCT116 cells. Furthermore, TNF- $\alpha$ induced morphological changes with either downregulation of E-cadherin or upregulation of $\mathrm{N}$-cadherin whereas DSGOST reversed TNF- $\alpha$-mediated changes. Furthermore, DSGOST suppressed TNF- $\alpha$-induced nuclear translocation of Snail via inhibition of AKT/GSK-3 $\beta$ pathways. Therefore, these results demonstrated for the first time, the inhibitory effect of DSGOST on TNF- $\alpha$-induced migration and invasion in HCT116 cells.

\section{Materials and methods}

Preparation of DSGOST. DSGOST powder was prepared as described previously (44). DSGOST consists of following herbal drugs; $1 \mathrm{~g}$ Angelica radix, $1 \mathrm{~g}$ Cinnamomi cortex, $1 \mathrm{~g}$ Paeoniae root, $1 \mathrm{~g}$ Akebia root, $0.67 \mathrm{~g}$ of Asarum, $0.67 \mathrm{~g}$ Glycyrrhiza, $1.67 \mathrm{~g}$ Zizyphus jujuba, $0.67 \mathrm{~g}$ Evodia fruit and $1.33 \mathrm{~g}$ ginger root. The dried mixture was dissolved in distilled water and stored at $-80^{\circ} \mathrm{C}$ until use.

Cell culture and cell viability assay. HCT116 human colorectal cancer cell lines were purchased from Korean Cell Line Bank (Seoul, Korea) and cultured in RPMI-1640 medium (Welgene Inc., Daegu, Korea)supplemented with $10 \%$ fetal bovine serum (FBS; JR Scientific, Woodland, CA, USA) and $1 \%$ penicillin/streptomycin solution. For cell viability assay, HCT116 cells were seeded at the density of 4,000 cells/well in 96-wells plate and then treated with DSGOST $(0,10,50$ and $100 \mu \mathrm{g} / \mathrm{ml})$. After $72 \mathrm{~h}$ incubation, cell viability was determined by 3-(4,5-dimethylthiazol-2-yl)-2,5-diphenyltetrazolium bromide (MTT) colorimetric assay with an absorbance $570 \mathrm{~nm}$.

Migration and invasion assay. For a cell migration assay, cells were cultured in 6 -wells plates until $100 \%$ confluence and then the monolayer was scratched the monolayer with a $200 \mu 1$ pipette tip. Cells were then pretreated with DSGOST for $2 \mathrm{~h}$ before incubation with TNF- $\alpha$ (R\&D Systems, Minneapolis, $\mathrm{MN}, \mathrm{USA}$ ) for $48 \mathrm{~h}$. The migrated area was analyzed by ImageJ software (64-bit Java 1.6.0_24; National Institutes of Health, Bethesda, MD, USA) and the average was calculated from independent experiments. For the invasion assay, Matrigel was mixed with coating buffer [0.01 $\mathrm{M}$ Tris $(\mathrm{pH} 8.0), 0.7 \% \mathrm{NaCl}]$ at 1:1 ratio and then added in upper side of BD Transwell chamber in 24-well plates for overnight incubation. HCT116 $\left(2 \times 10^{5}\right.$ cells $)$ were pre-incubated with $50 \mu \mathrm{g} / \mathrm{ml}$ DSGOST for $2 \mathrm{~h}$, followed by $20 \mathrm{ng} / \mathrm{ml}$ of TNF- $\alpha$ for $48 \mathrm{~h}$ in the upper chamber. Culture medium with $10 \%$ FBS as chemoattractant was added into the lower chamber. After $48 \mathrm{~h}$ incubation, the cells were fixed with $4 \%$ paraformaldehyde for $5 \mathrm{~min}$ and then permeabilized with $100 \%$ methanol for $20 \mathrm{~min}$. Non-invading cells were removed by cotton swab and the cells located at the underside of chamber were stained with $0.05 \%$ crystal violet for $20 \mathrm{~min}$ at room temperature. The four areas were randomly selected and cells were counted under a phase-contrast microscope.

Cellular fractionation. Cells were pretreated with DSGOST for $2 \mathrm{~h}$, followed by incubation with TNF- $\alpha$ for $6 \mathrm{~h}$. Cell lysates were suspended in $500 \mu \mathrm{l}$ hypotonic buffer $(20 \mathrm{mM}$ Tris- $\mathrm{HCl}$, $\mathrm{pH} 7.4,10 \mathrm{mM} \mathrm{NaCl}, 3 \mathrm{mM} \mathrm{MgCl}$ ) and incubated on ice for $15 \mathrm{~min}$, followed by centrifugation at $1,000 \mathrm{xg}$ at $4^{\circ} \mathrm{C}$. The supernatant (cytoplasmic fraction) was stored at $-80^{\circ} \mathrm{C}$ until use. The obtained pellets were suspended in $50 \mu \mathrm{l}$ cell extraction buffer containing $100 \mathrm{mM}$ Tris ( $\mathrm{pH} 7.4), 2 \mathrm{mM} \mathrm{Na}_{3} \mathrm{VO}_{4}$, $100 \mathrm{mM} \mathrm{NaCl}, 1 \%$ Triton X-100, $1 \mathrm{mM}$ ethylenediaminetetraacetic acid (EDTA), 10\% glycerol, 1 mM EGTA, 0.1\% sodium dodecyl sulfate (SDS), $1 \mathrm{mM} \mathrm{NaF}, 0.5 \%$ deoxycholate and $20 \mathrm{mM} \mathrm{Na}_{4} \mathrm{P}_{2} \mathrm{O}_{7}$. After incubation on ice for $15 \mathrm{~min}$, the mixture was centrifuged at $14,000 \mathrm{x}$ g at $4^{\circ} \mathrm{C}$. The supernatant (nuclear fraction) was stored at $-80^{\circ} \mathrm{C}$ until use.

Western blotting. Cells were collected by scraping and then lysed with RIPA buffer containing $50 \mathrm{mM}$ Tris-HCl, (pH 7.5), $150 \mathrm{mM} \mathrm{NaCl}, 1 \%$ Triton X-100, 2 mM EDTA, 0.1\% SDS and $1 \%$ sodium deoxycholate. Equal amount of proteins [20 $\mu \mathrm{g}$ per well; protein concentration was determined using a Bio-Rad Bradford protein assay (Bio-Rad, Hercules, CA, USA)] were separated by $10-12 \%$ SDS-PAGE, followed by transfer to nitrocellulose membranes. After blocking with $2 \%$ skim milk in PBS-Tween at room temperature for $1 \mathrm{~h}$, membranes were incubated with the appropriate antibodies at $4^{\circ} \mathrm{C}$ overnight. Anti-E-cadherin (cat. no. 3195, 1:1,000), tight junction protein-1 (ZO-1; cat. no. 8193; 1:500), N-cadherin (cat. no. 4061; 1:1,000), Snail (cat. no. 3879, 1:1,000), claudin-1 (cat. no. 13255; 1:500), p-AKT (cat. no. 9271; 1:500) and p-GSK-3ß (cat. no. 9336; 1:500) antibodies were purchased from Cell Signaling Technology, Inc. (Danvers, MA, USA). Anti-lamin B (cat. no. sc6216; 1:500) and $\beta$-actin (cat. no. sc47778; 1:2,000) antibodies were purchased from Santa Cruz Biotechnology, Inc. (Dallas, TX, USA). Horseradish peroxidase-conjugated secondary antibodies for mouse (cat. no. 7076; 1:1,000-3,000) and rabbit (cat. no. 7074; 1:1,000-2,000) were purchased from Cell Signaling Technology, Inc. The membranes were incubated with secondary antibodies for $1 \mathrm{~h}$ at room temperature. An enhanced chemiluminescence kit (DoGen, Seoul, Korea) was 
used for detection of HRP signal. ImageJ software (64-bit Java 1.6.0_24; National Institutes of Health) was used for densitometry.

Immunocytochemistry. The cells ( $80 \%$ confluency) were cultured on coverslip in 6-well plates with serum-free medium for $12 \mathrm{~h}$ and then pretreated with or without DSGOST. After $2 \mathrm{~h}$ incubation with DSGOST, cells were treated with TNF- $\alpha$ in medium with $1 \%$ FBS. Cells were washed with cold-PBS, fixed with $4 \%$ paraformaldehyde for $30 \mathrm{~min}$, permeabilized with $0.1 \%$ Triton $\mathrm{X}-100$ for 15 min and blocked with $2 \%$ bovine serum albumin (BSA) for $60 \mathrm{~min}$ at room temperature. Cells were washed with $0.5 \%$ BSA and were incubated with antibodies against E-cadherin (cat. no. 3195; 1:50), N-cadherin (cat. no. 4061; 1:50) and Snail (cat. no. 3879; 1:50) (Cell Signaling Technology, Inc.) at $4^{\circ} \mathrm{C}$ overnight. Following incubation, cells were incubated with Alexa Fluor 488-conjugated goat anti-rabbit IgG (cat. no. A-11008; 1:1,000; Thermo Fisher Scientific, Inc., Waltham, MA, USA) secondary antibodies for $1 \mathrm{~h}$ at room temperature. Nuclei were stained with TO-PRO-3 iodide (Thermo Fisher Scientific, Inc.). Confocal images were acquired with Zeiss LSM5 PASCAL confocal laser scanning microscope system (Carl Zeiss AG, Oberkochen, Germany). Fluorescence intensities were measured under the same condition for all experiments.

Statistical analysis. Data are presented as the mean \pm standard error or standard deviation from at least three experiments with three replicates per each experiment. The statistical differences of means between the groups were analyzed by one-way analysis of variance with post-hoc Tukey test using SPSS software version 22.0 (IBM Corp., Armonk, NY, USA). P<0.05 was considered to indicate a statistically significant difference.

\section{Results}

DSGOST inhibits TNF- $\alpha$-induced EMT in HCT116 cells. To avoid interference resulting from the anti-proliferative effect of DSGOST on HCT116 cells on HCT116 cells, the effect of DSGOST on proliferation of cells was examined by an MTT assay. DSGOST $(50 \mu \mathrm{g} / \mathrm{ml})$ did not affect on the proliferation of cells (Fig. 1A). Thus, the effect of DSGOST $(50 \mu \mathrm{g} / \mathrm{ml})$ on TNF- $\alpha$-mediated changes in morphology of cells was examined. While the cells in the TNF- $\alpha$ treatment group exhibited an invasive phenotype with a mesenchymal morphology, DSGOST treatment abrogated this change (Fig. 1B).

DSGOST reverses TNF- $\alpha$-mediated EMT in HCT116 cells. TNF- $\alpha$-induced invasive phenotype is associated with induction of EMT in colorectal cancer cells $(16,45)$. Whether DSGOST prevents TNF- $\alpha$-mediated changes in EMT markers was examined. Immunocytochemistry data demonstrated that TNF- $\alpha$ treatment induced mesenchymal morphology with decreased E-cadherin expression and increased $\mathrm{N}$-cadherin expression, whereas pretreatment of DSGOST inhibited TNF- $\alpha$-mediated responses (Fig. 2A). During EMT, epithelial cells acquire a mesenchymal-like phenotype, including the loss of E-cadherinmediated cell-cell adhesion and the upregulation of $\mathrm{N}$-cadherin. In TNF- $\alpha$-treated HCT116 cells, epithelial cell markers E-cadherin and ZO-1 were decreased while mesenchymal
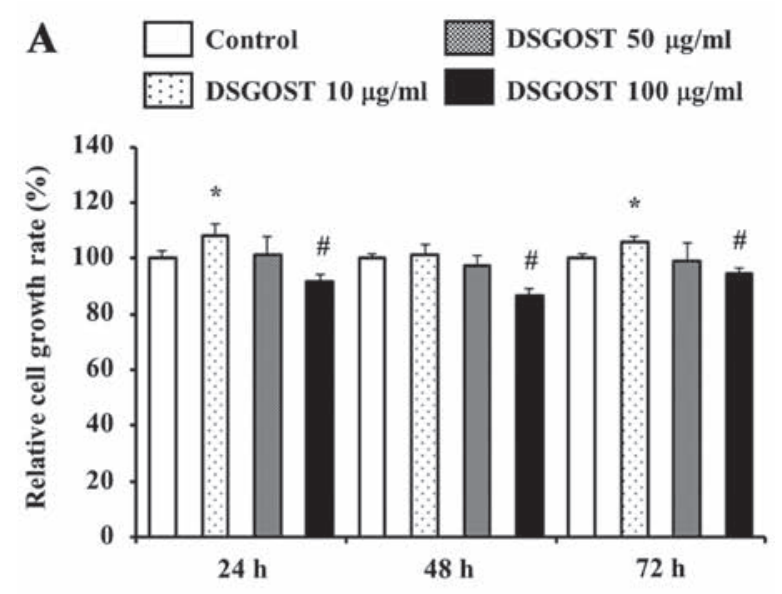

B

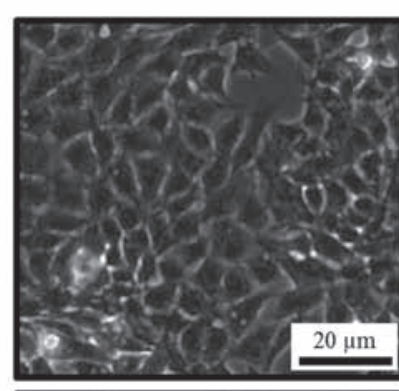

Control
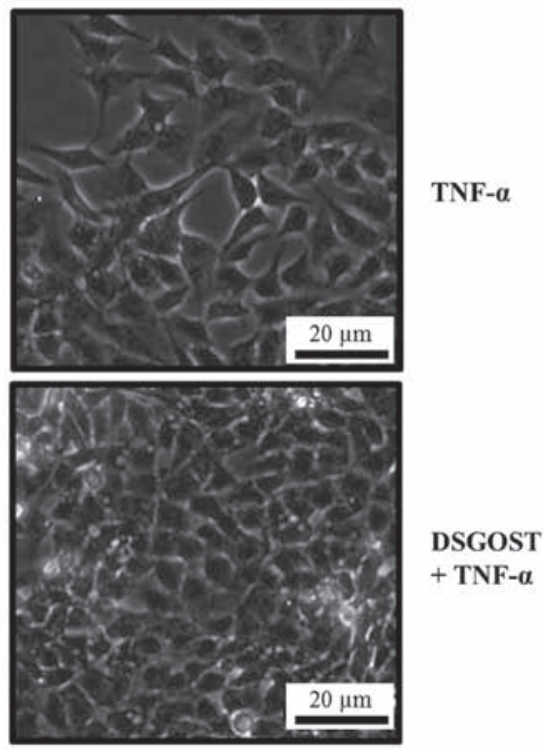

Figure 1. DSGOST inhibits TNF- $\alpha$-treated invasive phenotype of HCT116 cells. (A) Cell viability assay; 4,000 cells/well of 96-well plates were seeded and treated with indicated doses of DSGOST. Cell viability was measured by MTT assay (sample size of $n=3 /$ group). The experiment was performed on three times. Data are presented as the mean \pm standard error $\left({ }^{*} \mathrm{P}<0.05\right.$, control vs. DSGOST $10 \mu \mathrm{g} / \mathrm{ml}$; ${ }^{~} \mathrm{P}<0.05$, control vs. DSGOST $\left.100 \mu \mathrm{g} / \mathrm{ml}\right)$. (B) Cell morphology. The cells were cultured on coverslips in 6-well plates and pretreated with DSGOST $(50 \mu \mathrm{g} / \mathrm{ml})$ for $2 \mathrm{~h}$, followed by incubation with TNF- $\alpha(20 \mathrm{ng} / \mathrm{ml})$ for $48 \mathrm{~h}$. Phase contrast images were obtained by confocal microscopy. DSGOST, Danggui-Sayuk-Ga-Osuyu-Saenggang-Tang; TNF- $\alpha$, tumor necrosis factor- $\alpha$.

markers Snail, N-cadherin and claudin-1 were increased. Additionally, DSGOST treatment reversed TNF- $\alpha$-mediated protein expression (Fig. 2B and C). Thus, DSGOST is may inhibit TNF- $\alpha$-mediated EMT in HCT116 cells.

DSGOST suppresses TNF- $\alpha$-promoted migration and invasion of HCT116 cells. EMT process has been considered to 
$\mathbf{A}$

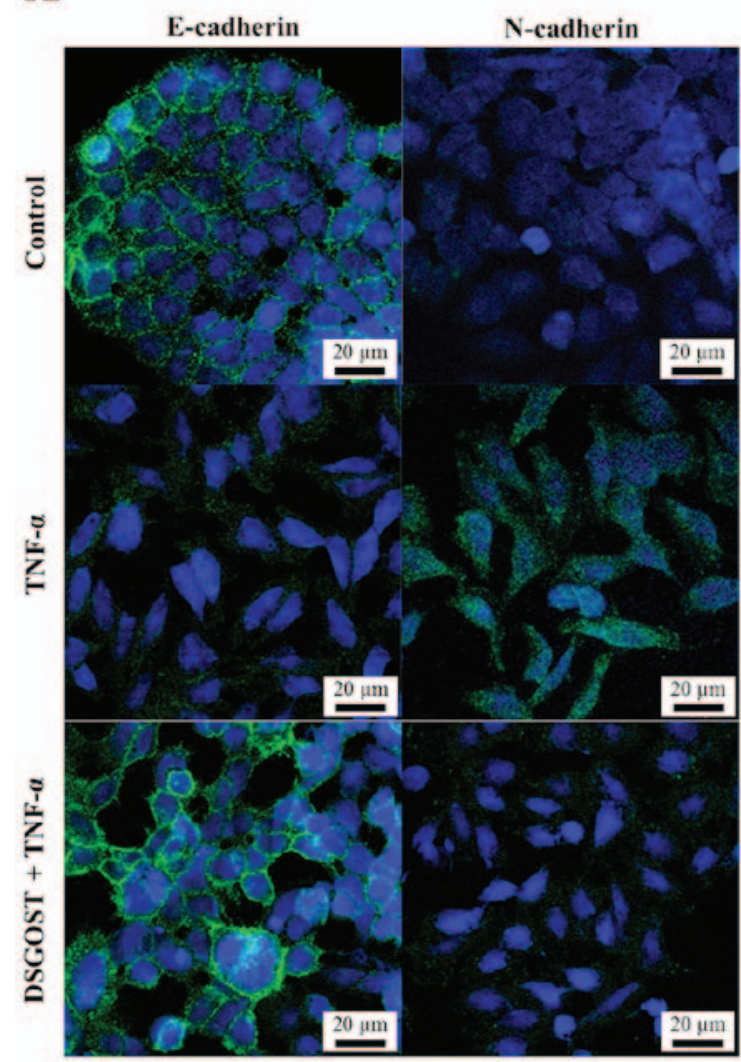

B
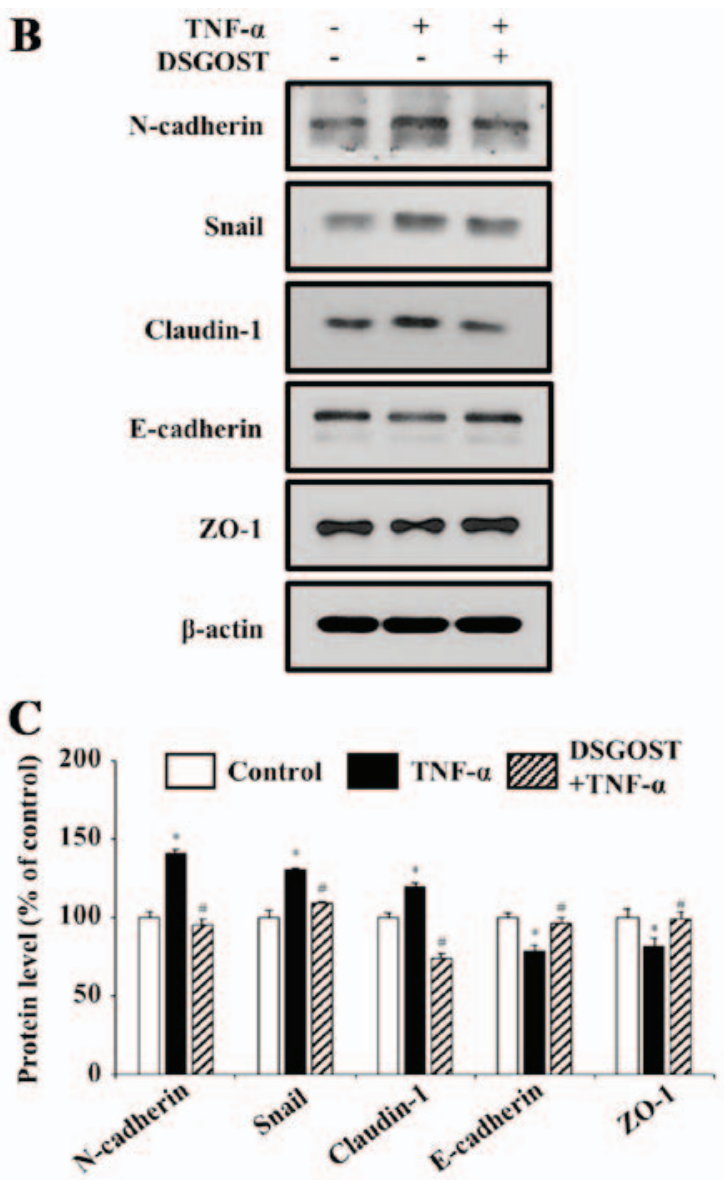

Figure 2. DSGOST reverses TNF- $\alpha$-mediated EMT in HCT116 cells. (A) Immunocytochemistry. Cells were cultured on coverslip in 6-well plates and pretreated with DSGOST $(50 \mu \mathrm{g} / \mathrm{ml})$ for $2 \mathrm{~h}$, followed by incubation with TNF- $\alpha(20 \mathrm{ng} / \mathrm{ml})$ for $48 \mathrm{~h}$. Cells were immunostained with E-cadherin and N-cadherin specific antibodies. Nuclei was stained with TO-PRO-3 iodide (blue). (B) Representative images and (C) densitometry from western blot analysis. Expression of EMT-associated proteins was analyzed by western blotting. $\beta$-actin was used as internal marker. The experiment was performed three times. Values are presented as the mean \pm standard deviation ("P $<0.05$, control vs. TNF- $\alpha$; ${ }^{*} \mathrm{P}<0.05$, TNF- $\alpha$ vs. DSGOST $+\mathrm{TNF}-\alpha$ ). EMT, epithelial-mesenchymal transition; DSGOST, Danggui-Sayuk-Ga-Osuyu-Saenggang-Tang; TNF- $\alpha$, tumor necrosis factor- $\alpha$; ZO-1, tight junction protein-1.
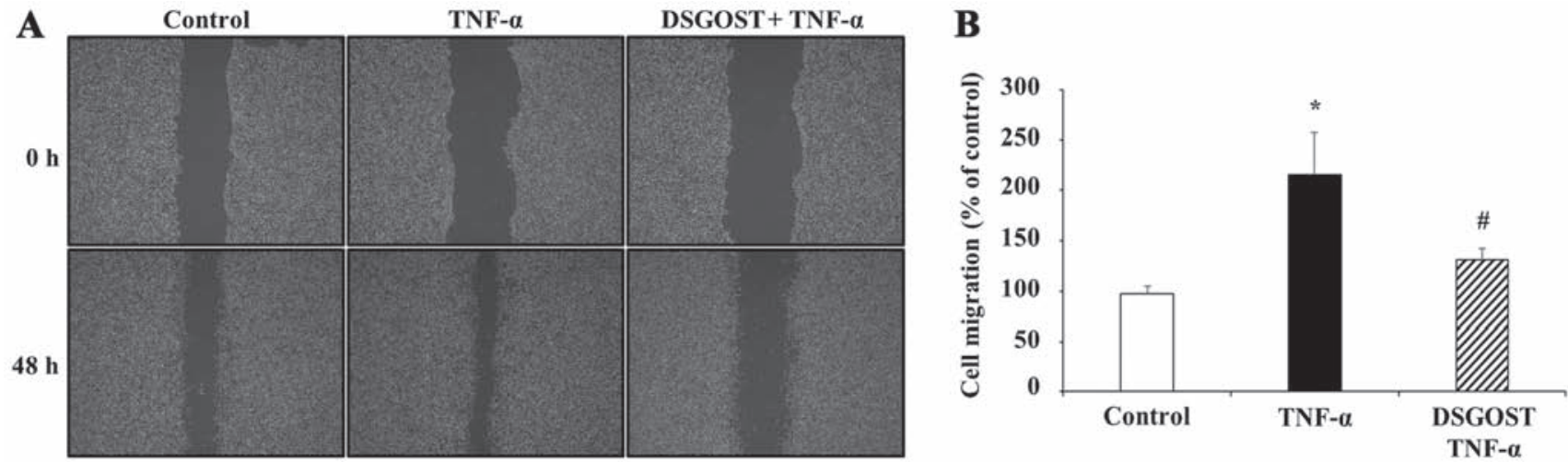

Figure 3. DSGOST inhibits TNF- $\alpha$-induced migration of HCT116 cells. (A) Representative images from wound healing assay. Cells were cultured on 6-well plates until 100\% confluent and then scratched. Cells were pretreated with DSGOST (50 $\mu \mathrm{g} / \mathrm{ml})$ for $2 \mathrm{~h}$, followed by incubation with TNF- $\alpha$ ( $20 \mathrm{ng} / \mathrm{ml})$ for $48 \mathrm{~h}$ (magnification, x40). (B) Migrated area (\% of control) was analyzed by ImageJ software. The experiment was performed on three times. Values are presented as the mean \pm standard deviation $\left(" \mathrm{P}<0.05\right.$, control vs. TNF- $\alpha$; ${ }^{\prime} \mathrm{P}<0.05$, TNF- $\alpha$ vs. DSGOST + TNF- $\alpha$ ). DSGOST, Danggui-Sayuk-Ga-Osuyu-SaenggangTang; TNF- $\alpha$, tumor necrosis factor- $\alpha$.

be a prerequisite for migration and invasion of various cell types (46). As DSGOST inhibited TNF- $\alpha$-induced EMT in HCT116 cells, it was also examined whether DSGOST suppresses TNF- $\alpha$-mediated migration and invasion using wound healing assay and Transwell invasion assays, respec- tively. TNF- $\alpha$ increased migration and invasion of HCT116 cells, and DSGOST treatment blocked TNF- $\alpha$-mediated migration and invasion (Figs. 3 and 4). Therefore, DSGOST is may suppress TNF- $\alpha$-induced migration and invasion of HCT116 cells. 
$\mathbf{A}$

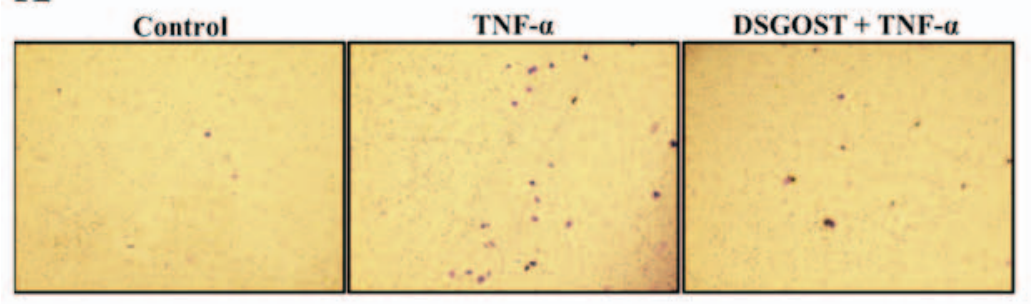

B

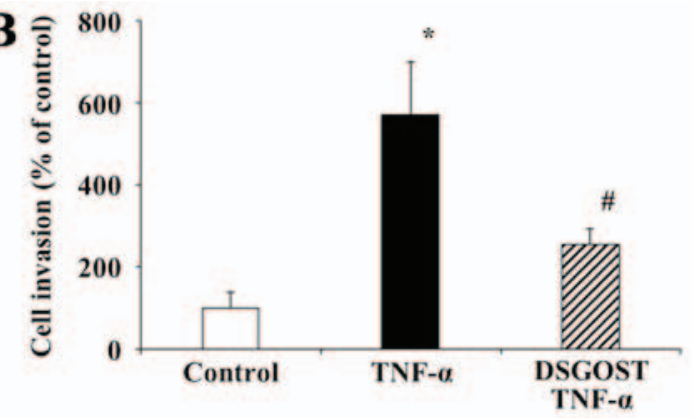

Figure 4. DSGOST inhibits TNF- $\alpha$-induced Transwell invasion of HCT116 cells. (A) Cells were cultured on Matrigel-coated Transwell chamber. Representative images from Transwell invasion assay. Cells were pretreated with DSGOST ( $50 \mu \mathrm{g} / \mathrm{ml})$ for $2 \mathrm{~h}$, followed by incubation with TNF- $\alpha$ ( $20 \mathrm{ng} / \mathrm{ml})$ for $48 \mathrm{~h}$ (magnification, $\mathrm{x} 40$ ). (B) Invading cells were counted under a microscope. The experiment was performed on three times. Graph indicates the mean \pm standard deviation $\left({ }^{*} \mathrm{P}<0.05\right.$, control vs. TNF- $\alpha$; ${ }^{\#} \mathrm{P}<0.05$, TNF- $\alpha$ vs. DSGOST + TNF- $\left.\alpha\right)$. DSGOST, Danggui-Sayuk-Ga-Osuyu-Saenggang-Tang; TNF- $\alpha$, tumor necrosis factor- $\alpha$.

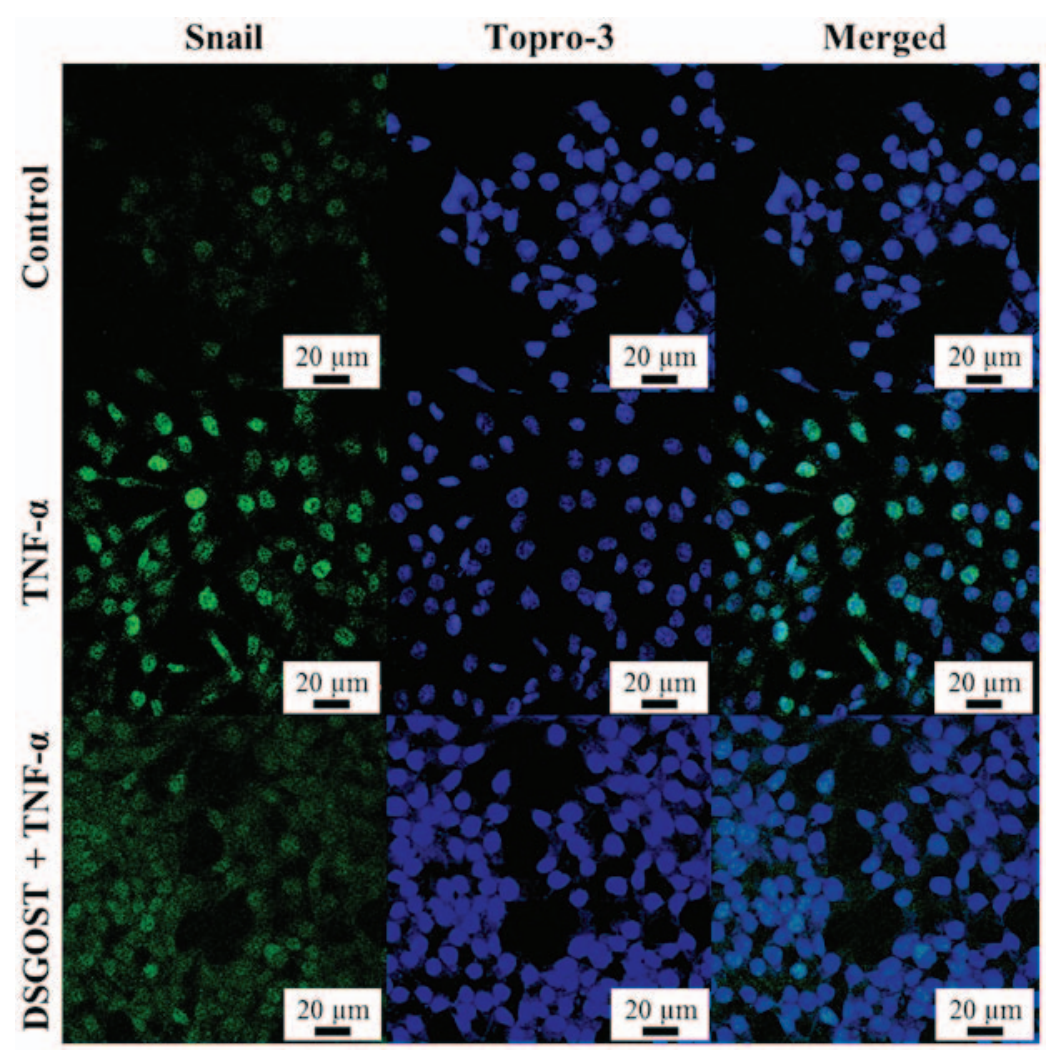

Figure 5. DSGOST blocks TNF- $\alpha$-induced Snail translocation into nuclei. Immunocytochemistry. Cells were cultured on coverslip in 6-well plates and pretreated with DSGOST $(50 \mu \mathrm{g} / \mathrm{ml})$ for $2 \mathrm{~h}$, followed by incubation with TNF- $\alpha(20 \mathrm{ng} / \mathrm{ml})$ for $48 \mathrm{~h}$. Cells were immunostained with Snail antibody (green). Nuclei was stained with TO-PRO-3 iodide (blue). DSGOST, Danggui-Sayuk-Ga-Osuyu-Saenggang-Tang; TNF- $\alpha$, tumor necrosis factor- $\alpha$.

DSGOST inhibits TNF- $\alpha$-induced nuclear translocation of Snail via inhibition of AKT/GSK-3 $\beta$ pathways in HCT116 cells. TNF- $\alpha$ activates either the expression or nuclear translocation of Snail protein, resulting in induction of EMT (16). As presented in Figs. 5 and 6, TNF- $\alpha$ promoted nuclear translocation of Snail protein, whereas pretreatment with DSGOST prevented this translocation. Thus, DSGOST inhibits TNF- $\alpha$-mediated EMT by suppressing Snail translocation into nucleus. As Snail is tightly regulated by GSK-3 $\beta$, which is phosphorylated and inactivated by AKT $(16,47)$, it was also further examined whether DSGOST inhibits TNF- $\alpha$-mediated AKT/GSK- $3 \beta$ signaling. While TNF- $\alpha$ induced the phosphorylation of both AKT and GSK-3 $\beta$, DSGOST inhibited their phosphorylation (Fig. 6B). Therefore, data indicated that
DSGOST inhibition of TNF- $\alpha$-induced Snail nuclear translocation is mediated by blocking the AKT/GSK-3 $\beta$ pathways.

\section{Discussion}

While DSGOST has been researched for the treatment of various disorders, recent studies have suggested DSGOST as a novel candidate for treatment of cancer $(42,43)$. Thus, we hypothesized that DSGOST would be an effective treatment for colorectal cancer. Since TNF- $\alpha$ activates the EMT process in colorectal cancer cells, resulting in tumor metastasis, the inhibitory effect of DSGOST treatment on TNF- $\alpha$-mediated migration and invasion of HCT116 cells was investigated in the current study. The findings showed that DSGOST suppressed 

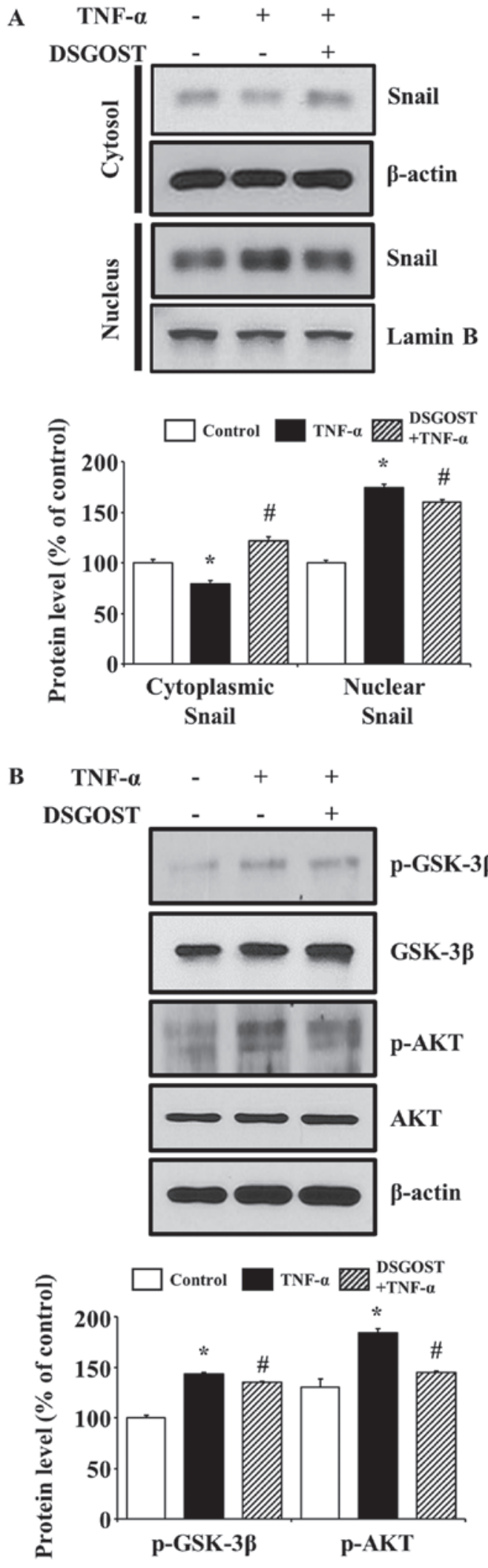

Figure 6. DSGOST blocks TNF- $\alpha$-induced Snail translocation into nuclei by downregulating AKT/pathways in HCT116 cells. Representative images from western blotting. Cells were pretreated with DSGOST $(50 \mu \mathrm{g} / \mathrm{ml})$ for $2 \mathrm{~h}$, followed by incubation with TNF- $\alpha$ ( $20 \mathrm{ng} / \mathrm{ml})$ for $6 \mathrm{~h}$. Expression of (A) Snail and (B) p-AKT and p-GSK-3 $\beta$ were analyzed by western blotting. $\beta$-actin and lamin B were used as cytosol and nucleus loading controls, respectively. The experiment was performed three times. Values are presented as the mean \pm standard deviation ( ${ }^{*} \mathrm{P}<0.05$, control vs. TNF- $\alpha$; ${ }^{\prime} \mathrm{P}<0.05$, TNF- $\alpha$ vs. DSGOST + TNF- $\alpha$ ). DSGOST, Danggui-Sayuk-Ga-Osuyu-Saenggang-Tang; TNF- $\alpha$, tumor necrosis factor- $\alpha$; AKT, protein kinase B; GSK-3 $\beta$, glycogen synthase kinase- $3 \beta$.
TNF- $\alpha$-mediated migration and invasion. Furthermore, DSGOST also blocked TNF- $\alpha$-mediated EMT via inhibiting AKT/GSK-3 $\beta /$ Snail signaling.

In the late 1970s, TNF- $\alpha$ was considered to be an anticancer agent by suppressing tumor cell proliferation $(48,49)$. On the other hand, several in vitro studies have reported the tumor promoting effect of TNF- $\alpha(16,50,51)$. Furthermore, clinical studies have reported that TNF- $\alpha$ expression levels in serum and tissues were elevated in patients with tumors (52-55), suggesting that TNF- $\alpha$ may be a prognostic marker in patients with cancer. While the role of TNF- $\alpha$ in tumor malignancy is still controversial, the effect of recombinant TNF- $\alpha$ on EMT in HCT116 cells was investigated in the current study. The data showed that TNF- $\alpha$ treatment induced EMT phenotype. Furthermore, TNF- $\alpha$ also promoted migration and invasion. Although the cell type, TNF- $\alpha$ concentration and incubation period of TNF- $\alpha$ in the present study were limited, and the precise mechanisms of the effects remain to be demonstrated, the data provide evidence that TNF- $\alpha$ may contribute to tumor metastasis by inducing EMT.

The role of Snail in EMT has been validated in several cancer types $(18-20,22)$. Poor clinical outcomes of patients with colorectal cancer are associated with Snail overexpression $(22,23)$. Wang et al (16) reported that TNF- $\alpha$-induced EMT is regulated by Snail protein in at least two types of colorectal cancer cells, HCT116 and Caco-2. Furthermore, the same study clearly showed that AKT/GSK-3 $\beta$ signaling is responsible for TNF- $\alpha$-mediated Snail stabilization in those cells, while inhibitors of nuclear factor- $\mathrm{kB}(\mathrm{NF}-\mathrm{\kappa} B), \mathrm{MAPK}$ and p38 failed to abrogate TNF- $\alpha$-induced Snail expression (16). Since Snail stabilization is tightly regulated by AKT/GSK-3 $\beta$ signaling pathways, DSGOST inhibition of AKT/GSK-3 $\beta$ signaling indicates that one of the potential biological mechanisms of DSGOST inhibition of TNF- $\alpha$-mediated EMT in HCT116 colorectal cancer cells is via blocking of AKT/GSK-3 $\beta /$ Snail signaling.

The potential effectiveness of multi-target approaches in cancer therapy has been emphasized previously (56). Phytochemicals and herbal mixtures, which may act on multiple targets, have anticancer activity (57-66). Genistein, a dietary component with an anticancer effects against breast and prostate cancer, has been shown to regulate apoptosis, cell cycle, and NF- $\kappa B$ and AKT pathways (58). Proanthocyanidins have been reported to exhibit anticancer effects via antioxidative and anti-inflammatory properties (59). Ginsenoside, from ginseng plants, modulates the immune system, apoptosis and metastasis (57). Traditional Chinese medicine theory-based multi-herb prescriptions have benefits in the treatment of diseases including breast (60) and lung (61) cancer. SH003, a herbal prescription composed of Astragalus membranaceus, Angelica gigas and Trichosanthes kirilowii Maximowicz, exerts inhibitory effects against tumor growth by targeting apoptosis, autophagy and angiogenesis in several cancer types (62,64-66). A previous study reported the antitumor and anti-angiogenesis effects of DSGOST (42). The present study also demonstrated that DSGOST inhibits TNF- $\alpha$-mediated invasion and migration of HCT116 cells. Since both invasive phenotype and tumor angiogenesis contribute to tumor metastasis and poor prognosis of patients with cancer, we hypothesize that the multi-target properties of DSGOST 
may be useful for improving the prognosis of patients with cancer by dual inhibition of invasion and tumor angiogenesis. However, further in vitro and in vivo studies are required to demonstrate the anticancer property of DSGOST with a clear biological mechanism in several cancer types.

In conclusion, the data of the current study demonstrates, that DSGOST inhibits TNF- $\alpha$-mediated EMT via suppressing AKT/GSK-3 $\beta /$ Snail pathways. Although the precise mechanism of DSGOST remains unclear, the results of the present study suggests that DSGOST is potentially beneficial for treating colorectal cancer. Furthermore, taken together with previous results indicating DSGOST inhibition of tumor angiogenesis, this suggests that DSGOST may be a novel multi-target herbal medicine for inhibition of tumor metastasis.

\section{Acknowledgements}

This study was supported by a grant from Korean Medicine R\&D Project of the Ministry of Health and Welfare (grant no. B110043).

\section{References}

1. Siegel R, Desantis C and Jemal A: Colorectal cancer statistics, 2014. CA Cancer J Clin 64: 104-117, 2014.

2. Pourhoseingholi MA: Increased burden of colorectal cancer in Asia. World J Gastrointest Oncol 4: 68-70, 2012.

3. Siegel RL, Miller KD and Jemal A: Cancer statistics, 2015. CA Cancer J Clin 65: 5-29, 2015.

4. Tournigand C, André T, Achille E, Lledo G, Flesh M, Mery-Mignard D, Quinaux E, Couteau C, Buyse M, Ganem G, et al: FOLFIRI followed by FOLFOX6 or the reverse sequence in advanced colorectal cancer: A randomized GERCOR study. J Clin Oncol 22: 229-237, 2004.

5. Van Cutsem E, Köhne CH, Hitre E, Zaluski J, Chang Chien CR, Makhson A, D'Haens G, Pintér T, Lim R, Bodoky G, et al: Cetuximab and chemotherapy as initial treatment for metastatic colorectal cancer. N Engl J Med 360: 1408-1417, 2009.

6. Adam R, Avisar E, Ariche A, Giachetti S, Azoulay D, Castaing D, Kunstlinger F, Levi F and Bismuth F: Five-year survival following hepatic resection after neoadjuvant therapy for nonresectable colorectal. Ann Surg Oncol 8: 347-353, 2001.

7. Hamilton TD, Leugner D, Kopciuk K, Dixon E, Sutherland FR and Bathe OF: Identification of prognostic inflammatory factors in colorectal liver metastases. BMC Cancer 14: 542, 2014.

8. Weiss L, Grundmann E, Torhorst J, Hartveit F, Moberg I, Eder M, Fenoglio-Preiser CM, Napier J, Horne CH, Lopez MJ, et al: Haematogenous metastatic patterns in colonic carcinoma: An analysis of 1541 necropsies. J Pathol 150: 195-203, 1986.

9. Noura S, Ohue M, Shingai T, Fujiwara A, Imada S, Sueda T, Yamada T, Fujiwara Y, Ohigashi H, Yano M, et al: Brain metastasis from colorectal cancer: Prognostic factors and survival. J Surg Oncol 106: 144-148, 2012.

10. Jimi S, Yasui T, Hotokezaka M, Shimada K, Shinagawa Y, Shiozaki H, Tsutsumi N and Takeda S: Clinical features and prognostic factors of bone metastases from colorectal cancer. Surg Today 43: 751-756, 2013.

11. Terzic J, Grivennikov S, Karin E and Karin M: Inflammation and colon cancer. Gastroenterology 138: 2101-2114 e2105, 2010.

12. Balkwill FR and Mantovani A: Cancer-related inflammation: Common themes and therapeutic opportunities. Semin Cancer Biol 22: 33-40, 2012.

13. Klampfer L: Cytokines, inflammation and colon cancer. Curr Cancer Drug Targets 11: 451-464, 2011.

14. Balkwill F: Tumour necrosis factor and cancer. Nat Rev Cancer 9: 361-371, 2009.

15. Balkwill F: TNF-alpha in promotion and progression of cancer. Cancer Metastasis Rev 25: 409-416, 2006.

16. Wang H, Wang HS, Zhou BH, Li CL, Zhang F, Wang XF, Zhang G, Bu XZ, Cai SH and Du J: Epithelial-mesenchymal transition (EMT) induced by TNF- $\alpha$ requires AKT/GSK-3 $\beta$-mediated stabilization of snail in colorectal cancer. PLoS One 8: e56664, 2013.
17. Peinado H, Olmeda D and Cano A: Snail, Zeb and bHLH factors in tumour progression: An alliance against the epithelial phenotype? Nat Rev Cancer 7: 415-428, 2007.

18. Dong C, Wu Y, Yao J, Wang Y, Yu Y, Rychahou PG, Evers BM and Zhou BP: G9a interacts with Snail and is critical for Snail-mediated E-cadherin repression in human breast cancer. J Clin Invest 122: 1469-1486, 2012.

19. Pon YL, Zhou HY, Cheung AN, Ngan HY and Wong AS: p70 S6 kinase promotes epithelial to mesenchymal transition through snail induction in ovarian cancer cells. Cancer Res 68: 6524-6532, 2008.

20. Wang J, Zhu X, Hu J, He G, Li X, Wu P, Ren X, Wang F, Liao W, Liang L, et al: The positive feedback between Snail and DAB2IP regulates EMT, invasion and metastasis in colorectal cancer. Oncotarget 6: 27427-27439, 2015.

21. Bates RC and Mercurio AM: The epithelial-mesenchymal transition (EMT) and colorectal cancer progression. Cancer Biol Ther 4: 365-370, 2005

22. Kroepil F, Fluegen G, Vallböhmer D, Baldus SE, Dizdar L, Raffel AM, Hafner D, Stoecklein NH and Knoefel WT: Snaill expression in colorectal cancer and its correlation with clinical and pathological parameters. BMC Cancer 13: 145, 2013.

23. Kwon CH, Park HJ, Choi JH, Lee JR, Kim HK, Jo HJ, Kim HS, Oh N, Song GA and Park DY: Snail and serpinA1 promote tumor progression and predict prognosis in colorectal cancer. Oncotarget 6: 20312-20326, 2015.

24. Zhang W and Liu HT: MAPK signal pathways in the regulation of cell proliferation in mammalian cells. Cell Res 12: 9-18, 2002.

25. Fresno Vara JA, Casado E, de Castro J, Cejas P, Belda-Iniesta C and González-Barón M: PI3K/Akt signalling pathway and cancer. Cancer Treat Rev 30: 193-204, 2004.

26. McCubrey JA, Steelman LS, Bertrand FE, Davis NM, Sokolosky M, Abrams SL, Montalto G, D'Assoro AB, Libra M, Nicoletti F, et al: GSK-3 as potential target for therapeutic intervention in cancer. Oncotarget 5: 2881-2911, 2014.

27. Pappalardo F, Russo G, Candido S, Pennisi M, Cavalieri S, Motta S, McCubrey JA, Nicoletti F and Libra M: Computational modeling of PI3K/AKT and MAPK signaling pathways in melanoma cancer. PLoS One 11: e0152104, 2016.

28. Ciuffreda L, McCubrey JA and Milella M: Signaling intermediates (PI3K/PTEN/AKT/mTOR and RAF/MEK/ERK pathways) as therapeutic targets for anticancer and anti-angiogenesis treatments. Curr Signal Transduct Ther 4: 130-143, 2009.

29. El Touny LH and Banerjee PP: Akt GSK-3 pathway as a target in genistein-induced inhibition of TRAMP prostate cancer progression toward a poorly differentiated phenotype. Carcinogenesis 28: 1710-1717, 2007.

30. Bocca C,Bozzo F, Bassignana A and Miglietta A: Antiproliferative effects of COX-2 inhibitor celecoxib on human breast cancer cell lines. Mol Cell Biochem 350: 59-70, 2011.

31. Firdous AB, Sharmila G, Balakrishnan S, RajaSingh P, Suganya S, Srinivasan N and Arunakaran J: Quercetin, a natural dietary flavonoid, acts as a chemopreventive agent against prostate cancer in an in vivo model by inhibiting the EGFR signaling pathway. Food Funct 5: 2632-2645, 2014

32. Yim NH, Jung YP, Kim A, Ma CJ, Cho WK and Ma JY: Oyaksungisan, a traditional herbal formula, inhibits cell proliferation by induction of autophagy via JNK activation in human colon cancer cells. Evid Based Complement Alternat Med 2013: 231874, 2013

33. Hou F, Li W, Shi Q, Li H, Liu S, Zong S, Ren J, Chai J and Xu J: Yi Ai Fang, a traditional Chinese herbal formula, impacts the vasculogenic mimicry formation of human colorectal cancer through HIF-1 $\alpha$ and epithelial mesenchymal transition. BMC Complement Altern Med 16: 428, 2016.

34. Ohnishi Y, Fujii H, Hayakawa Y, Sakukawa R, Yamaura T, Sakamoto T, Tsukada K, Fujimaki M, Nunome S, Komatsu Y, et al: Oral administration of a Kampo (Japanese herbal) medicine Juzen-taiho-to inhibits liver metastasis of colon 26-L5 carcinoma cells. Jpn J Cancer Res 89: 206-213, 1998.

35. Leung WK, Wu JC, Liang SM, Chan LS, Chan FK, Xie H, Fung SS, Hui AJ, Wong VW, Che CT, et al: Treatment of diarrhea-predominant irritable bowel syndrome with traditional Chinese herbal medicine: A randomized placebo-controlled trial. Am J Gastroenterol 101: 1574-1580, 2006.

36. Hosokawa A, Ogawa K, Ando T, Suzuki N, Ueda A, Kajiura S, Kobayashi Y, Tsukioka Y, Horikawa N, Yabushita K, et al: Preventive effect of traditional Japanese medicine on neurotoxicity of FOLFOX for metastatic colorectal cancer: A multicenter retrospective study. Anticancer Res 32: 2545-2550, 2012. 
37. Yoshikawa K, Shimada M, Nishioka M, Kurita N, Iwata T, Morimoto S, Miyatani T, Komatsu M, Kashihara H and Mikami C: The effects of the Kampo medicine (Japanese herbal medicine) 'Daikenchuto' on the surgical inflammatory response following laparoscopic colorectal resection. Surg Today 42: 646-651, 2012.

38. Tsukada R, Yamaguchi T, Hang L, Iseki M, Kobayashi H and Inada E: Effect of a traditional Japanese medicine goshajinkigan, tokishigyakukagoshuyushokyoto on the warm and cold sense threshold and peripheral blood flow. Health (NY) 6: 757-763, 2014.

39. Yoko K, Akira T and Hiroshi S: Efficacy of Kampo formula Tokishigyakukagoshuyushokyoto for cold syndrome evaluated with a novel clinical method using a patient-based questionnaire database. Kampo Med 63: 299-304, 2012.

40. Oya A, Oikawa T, Nakai A, Takeshita T and Hanawa T: Clinical efficacy of Kampo medicine (Japanese traditional herbal medicine) in the treatment of primary dysmenorrhea. J Obstet Gynaecol Res 34: 898-908, 2008.

41. Hiromi K, Hisashi T, Shigeto Y, Takeshi N, Nobuyuki M, Daisuke T and Masamitsu I: Usefulness of Kampo formulas in the treatment of atopic dermatitis. J Tradit Medicines 29: 93-96, 2012.

42. Choi HS, Lee K, Kim MK, Lee KM, Shin YC, Cho SG and Ko SG: DSGOST inhibits tumor growth by blocking VEGF/VEGFR2-activated angiogenesis. Oncotarget 7: 21775-21785, 2016.

43. Nagata T, Toume K, Long LX, Hirano K, Watanabe T, Sekine S, Okumura T, Komatsu K and Tsukada K: Anticancer effect of a Kampo preparation Daikenchuto. J Nat Med 70: 627-633, 2016.

44. Lee K, Cho SG, Woo SM, Kim AJ, Lee KM, Go HY, Sun SH, Kim TH, Jung KY, Choi YK, et al: Danggui Sayuk Ga Osuyu Senggang Tang ameliorates cold induced vasoconstriction in vitro and in vivo. Mol Med Rep 14: 4723-4728, 2016.

45. Bates RC and Mercurio AM: Tumor necrosis factor-alpha stimulates the epithelial-to-mesenchymal transition of human colonic organoids. Mol Biol Cell 14: 1790-1800, 2003.

46. Christiansen JJ and Rajasekaran AK: Reassessing epithelial to mesenchymal transition as a prerequisite for carcinoma invasion and metastasis. Cancer Res 66: 8319-8326, 2006.

47. Zhou BP, Deng J, Xia W, Xu J, Li YM, Gunduz M and Hung MC: Dual regulation of Snail by GSK-3 beta-mediated phosphorylation in control of epithelial-mesenchymal transition. Nat Cell Biol 6: 931-940, 2004.

48. Green S, Dobrjansky A and Chiasson MA: Murine tumor necrosis-inducing factor: Purification and effects on myelomonocytic leukemia cells. J Natl Cancer Inst 68: 997-1003, 1982.

49. Carswell EA, Old LJ, Kassel RL, Green S, Fiore N and Williamson B: An endotoxin-induced serum factor that causes necrosis of tumors. Proc Natl Acad Sci USA 72: 3666-3670, 1975.

50. Wu Y and Zhou BP: TNF-alpha/NF-kappaB/Snail pathway in cancer cell migration and invasion. Br J Cancer 102: 639-644, 2010.

51. Zins K, Abraham D, Sioud M and Aharinejad S: Colon cancer cell-derived tumor necrosis factor-alpha mediates the tumor growth-promoting response in macrophages by upregulating the colony-stimulating factor-1 pathway. Cancer Res 67: 1038-1045, 2007.
52. Ferrajoli A, Keating MJ, Manshouri T, Giles FJ, Dey A, Estrov Z Koller CA, Kurzrock R, Thomas DA, Faderl S, et al: The clinical significance of tumor necrosis factor-alpha plasma level in patients having chronic lymphocytic leukemia. Blood 100: 1215-1219, 2002.

53. Csiszár A, Szentes T, Haraszti B, Balázs A, Petrányi GG and Pócsik E: The pattern of cytokine gene expression in human colorectal carcinoma. Pathol Oncol Res 10: 109-116, 2004.

54. Grimm M, Lazariotou M, Kircher S, Höfelmayr A, Germer CT, von Rahden BH, Waaga-Gasser AM and Gasser M: Tumor necrosis factor- $\alpha$ is associated with positive lymph node status in patients with recurrence of colorectal cancer-indications for anti-TNF- $\alpha$ agents in cancer treatment. Cell Oncol (Dordr) 34: 315-326, 2011.

55. Al Obeed OA, Alkhayal KA, Al Sheikh A, Zubaidi AM, Vaali-Mohammed MA, Boushey R, Mckerrow JH and Abdulla MH: Increased expression of tumor necrosis factor- $\alpha$ is associated with advanced colorectal cancer stages. World J Gastroenterol 20: 18390-18396, 2014.

56. Petrelli A and Giordano S: From single- to multi-target drugs in cancer therapy: When aspecificity becomes an advantage. Curr Med Chem 15: 422-432, 2008.

57. Attele AS, Wu JA and Yuan CS: Ginseng pharmacology: Multiple constituents and multiple actions. Biochem Pharmacol 58: 1685-1693, 1999.

58. Banerjee S, Li Y, Wang Z and Sarkar FH: Multi-targeted therapy of cancer by genistein. Cancer Lett 269: 226-242, 2008.

59. Nandakumar V, Singh T and Katiyar SK: Multi-targeted prevention and therapy of cancer by proanthocyanidins. Cancer Lett 269: 378-387, 2008.

60. Gao JL, He TC, Li YB and Wang YT: A traditional Chinese medicine formulation consisting of Rhizoma Corydalis and Rhizoma Curcumae exerts synergistic antitumor activity. Oncol Rep 22: 1077-1083, 2009.

61. Di Maio M, Costanzo R, Giordano P, Piccirillo MC, Sandomenico C, Montanino A, Carillio G, Muto P, Jones DR, Daniele $\mathrm{G}$, et al: Integrated therapeutic approaches in the treatment of locally advanced non-small cell lung cancer. Anticancer Agents Med Chem 13: 844-851, 2013

62. Choi YJ, Choi YK, Lee KM, Cho SG, Kang SY and Ko SG: SH003 induces apoptosis of DU145 prostate cancer cells by inhibiting ERK-involved pathway. BMC Complement Altern Med 16: 507, 2016.

63. Choi EK, Kim SM, Hong SW, Moon JH, Shin JS, Kim JH, Hwang IY, Jung SA, Lee DH, Lee EY, et al: SH003 selectively induces p73 dependent apoptosis in triple negative breast cancer cells. Mol Med Rep 14: 3955-3960, 2016.

64. Choi YK, Cho SG, Choi YJ, Yun YJ, Lee KM, Lee K, Yoo HH, Shin YC and Ko SG: SH003 suppresses breast cancer growth by accumulating p62 in autolysosomes. Oncotarget: Aug 19, 2016 (Epub ahead of print).

65. Choi HS, Kim MK, Lee K, Lee KM, Choi YK, Shin YC, Cho SG and Ko SG: SH003 represses tumor angiogenesis by blocking VEGF binding to VEGFR2. Oncotarget 7: 32969-32979, 2016.

66. Choi YK, Cho SG, Woo SM, Yun YJ, Park S, Shin YC and Ko SG: Herbal extract $\mathrm{SH} 003$ suppresses tumor growth and metastasis of MDA-MB-231 breast cancer cells by inhibiting STAT3-IL-6 signaling. Mediators Inflamm 2014: 492173, 2014. 